\title{
The Management of Indonesian Navy Personnel Based on Competence to Achieve More Optimum Performance
}

\author{
Heribertus Yudho Warsono ${ }^{1}$, Budiyanto ${ }^{2}$, Akhmad Riduwan ${ }^{3}$ \\ ${ }^{1,2,3}$ Sekolah Tinggi Ilmu Ekonomi Indonesia, STIESIA \\ Surabaya, Indonesia
}

\begin{abstract}
The importance of the role of Human Resource management that is closely related to performance, in this case is the Indonesian Navy personnel. There is a must-have for every personnel to improve the optimal performance of competence development. The problem discussed in this research is how to improve the performance of Navy Personnel. The purpose of this research is to know the relation of competence to Navy performance support instrument and to analyze the influence of Human Resources on Navy performance. The method used is descriptive analysis of the influence of Human Resources on performance. Based on the results of the study, a person with adequate experience and technical qualifications, not necessarily have good performance, if the concerned is unable to show the behavior that supports the implementation of the task
\end{abstract}

Keyword: Indonesian Navy, Human Resources, Performance Employee

\section{Introduction}

Employee satisfaction depends very much on the positive and / or negative feelings a person has for himself or herself as well his job [1]. Employee job satisfaction is very important role in the performance of an organization. This is important to know so how employees can be maintained [2]. Human Resources (HR) in this regard are said to be one of the main driving factors in the achievement of organizational goals (companies) [3]. The Employee Management process is the most important aspect of the organization process [4]. The position and role of the Navy as the main element of defense force in the Sea which has the main duty and function according to Law Number 34 Year 2004, namely the Indonesian Forces is required to take an active role in maintaining the sovereignty of The Unitary State of the Republic of Indonesia based on loyalty and obedience to Pancasila and the 1945 Constitution.

In the management of human resources is required management capable of managing resources in a systematic, planned, and efficient. In an organization, Human Resources is human life [5]. In order to carry out its main duty and function properly, the development of Navy personnel is directed to improve the quality of human resources, in order to have attitude and behavior so as to provide the best service and high performance for the glory of the nation and the State.

Work / life balance is very important and affects employee attitudes towards the organization and life of the employees themselves [6]. The implementation of state defense rests on the strength and capability of human resources, namely the Indonesian people, both military and non-military, supported by reliable weapons and defense systems, so that quality human resources are the center of strength for National Defense.

Performance an employee can greatly help leaders to create a decision toward an excellent organization [7]. Human resources is often referred to as human resources, human power or power. Resources are also called power sources, abilities, strengths, skills possessed by humans. Along with technological developments and changes of the increasingly complex world, requires a person to always refresh his ability in accordance with the capacity of the change. One of the ways that can and is important to do in an effort empowering employees in creating job satisfaction is to motivate communicated [8]. Basically, humans have the basic potential and ability that ideally will continue to grow when sharpened continuously and sustainably. 
Ministry of Defense of Indonesia 2008 stated that improving the quality and welfare of human resources of defense become one of the main target besides efforts to increase defense capability, rejuvenation and addition of the main tool of weapons systems and improvement of technology and domestic defense industry. The problem statements are how to improve the performance of the Navy soldiers and what the factors that affect the performance of Navy soldiers, and how the relation of influence of human resources to Navy performance.

This paper is structured as follows. Section 1 describes the background and problems statement, Section 2 presents an analysis of human resources and performance relationships in the Indonesian Navy. Section 3 describes the results obtained from the research in the Indonesian Navy. Section 4 presents the conclusions of the paper. The inscriptive benefit of this paper is to enrich the analysis and to know the correlation between human resources and the performance of Navy soldiers. Second, provide empirical evidence through a descriptive study of the planning process, the implementation so that results relating to the implementation of duties in the Indonesian Navy.

\section{Material And Method \\ Human Resources.}

Human Resources is an integrated ability of the power of thought and physical power possessed by individuals. Perpetrators and nature are done by heredity and environment, while her work performance is motivated by desire to fulfill her satisfaction. According to Human Resources consists of the power of thinking and physical power of every human being. The assertiveness of every human being is determined by his power of thought and physical power. Human or human resources become the main element in every activity undertaken. Reliable or sophisticated equipment without the active role of Human Resources, does not mean anything. Power of thought is the intelligence that is brought from birth while the ability is obtained from the effort through learning and training. Intelligence quotes Intelligence Quotient and Emotion Quality.

Human resources are a very critical factor as a major asset in an agency. Its existence in the system with all its uniqueness that determines the success becomes very important to note. To that end, agencies should develop management strategies well and neatly arranged. The human capability factor in doing the job is strongly influenced by the competencies that exist in each himself so that Human Resource Management based on the management of competence sees that the need for the output of each worker makes competence as the main foundation for all functions in the Source Management Human Power. Competence drives the process of designing work systems, recruitment, placement, performance management, and with all functions in human resource management. Therefore, each person must have criteria and size of competence that each different and has its own characteristics.

But not everyone can meet the demands of his competence. Therefore, it is also necessary to identify, measure and analyze the competencies and management so that the functions of competency development programs on human resources can be developed through appropriate competency improvement programs, for example by training programs, coaching, and or counselling. Several objectives for agencies related to competency-based human resource management, for example:

a. All positions within the organization can function properly (according to the demands of their work),

b. Provide guidance to all holder of office in order to meet the standard of competency standard that has been determined,

c. As a basis for human resource management to develop competency and career development programs based on the results of competency measurement that is compared with the requirements on the competence of the position it holds,

d. To improve one's competence if at the time of competence measurement it is found that the competence has not been able to fulfill the competency requirement of the office through training, coaching, and / or counseling program.

In developing the process of competency-based human resources management is expected every component in the agency can feel the benefits.

\section{Indonesian Navy.}


The Indonesian Navy is a part of the Indonesian National Armed Forces responsible for the defense operations of the Republic of Indonesia in the Sea. The Indonesian Navy was formed on September 10, 1945. The Indonesian Navy is lead by a Navy Chief of Staff who is the highest leader in the Navy Headquarters. In carrying out the main tasks, the Indonesian Navy has a defense function and enforce the law of the Sea carried out by the Main command in the Indonesian Navy. Main Command in the Indonesian Naval Army there is a Fleet Command, under the Command of the fleet there is the Main Base of the Indonesian Navy, in addition Command Fleet also has the Operation Unit, the Marine Combat Task Force and Sea Security Group and Implementing Unit (Fast Ship Unit, Amphibian Ship, Submarine etc.). Under the Main Base there is the Indonesian Naval Base. As for the Implementing Unit oversees the fleet of the warships.

\section{Correlation between Human Resourses and The Indonesian Navy.}

To build a World Class Navy, the priority is to build character, both individual characters, units and organization of the Navy as a whole and comprehensive. Character required is superior, special, and high quality or called "Excellent". Excellent in three areas namely Organization (Organizationally Excellent), Operational (Operationally Excellent) and Human Resources (Excellent Manpower).

State sovereignty, state defense and the Indonesian Armed Forces are three things that cannot be separated, because in carrying out the defense of the state to guarantee the establishment of the Unitary State of the Republic of Indonesia, which became the main component is the Indonesian National Army. Therefore, establishing the Indonesian National Army and its ranks to be strong, solid and professional is a necessity at this time.

However, building the Indonesian National Army, especially the Indonesian Navy is not as easy as it is now, because building the Indonesian Navy as a large military organization requires the attention and cooperation of all components of the nation. Because building the Indonesian Navy requires the existence of policies, regulations, budgets and improvements posture. As we know after the reformation, the Indonesia National Army faces a lot of blasphemy and criticism from various circles, besides the state's own financial condition has not fully improved, so the budget support to the defense sector is also very limited which in the end becomes an obstacle in the development of the Indonesian Navy.

The Indonesian Navy as one of the dimensions in the Indonesian National Army currently has a period, where between the demands of the task and the nature of the threat of placing the Indonesian Navy in a difficult position, because up to now to be able to meet the minimum needs of its essential force is still difficult to achieve, while the nature of the threat increasingly complex in line with the development of the era. The real threat currently faced by the nation and the country of Indonesia is the number of internal conflicts both vertical and horizontal conflicts that can threaten the integrity of the Unitary State of the Republic of Indonesia, not to mention the threat from outside countries that try to tamper with the sovereignty of the Unitary State of the Republic of Indonesia through the shift of the boundary territory, annexation and claims of the islands, and the guarding of our outer islands which are very vulnerable to disruption and control by other countries.

Such things ultimately lead to a reflection in our hearts, can the Indonesian Navy safeguard the sovereignty of the Unitary State of the Republic of Indonesia, and can we build a reliable and respected and world-class Indonesian Navy. Contemplation like this should we can realize, because the Indonesian Navy is a reliable and respected and world-class, is one tool to achieve the goals and national ideals of Indonesia. although it takes time but at least there is a solution that can be used and applied to lead to the achievement of a reliable and respected and world-class organization of the Indonesian Navy.

The development of military organization as a responsible institution in the field of defense has a distinct characteristic, because military organization besides having 3 (three) main factor of organizers are: 1) People, 2) Cooperation and 3) Specific purpose, where the three factors is interrelated and inseparable, it also has additional factors according to its characteristics, in this case is the existence of doctrine in carrying out the strategy of state defense. It was from this doctrine that then gave birth to policies, basic principles and strategic measures of defense resource management to build military organizations in order to achieve national goals.

Similarly, the Indonesian Navy as a military organization that has the main duty, among others, carry out the task of the Indonesian Military National Defense in the field of defense, carry out the task of the Indonesian National Army in the development and development of marine power, all forms of activities 
undertaken by the Indonesian Navy both in the form of policies and management of its defense resources directed in order to form a reliable and respected and world-class organization of the Indonesian Navy. Therefore the Indonesian Navy's defense resources management policy should refer to the defense strategy of the country. So that the translation can be integrated with other dimensions.

Companies in any field, big or small, of course all want the maximum results of business and sacrifices that have been issued. Emptiness in humans raise the motivation for growth [9]. To achieve high employee productivity required high employee motivation as well [10]. As explained earlier, the main factor of the organization is the person / human being, because only with the presence of people / humans then an organization can run as it should. Similarly, the Indonesian Navy, as a military organization of the Indonesian Navy in addition to having basic requirements of the organization is also equipped with equipment and weapons that require good manners / handling for the organization to walk and the goals outlined well achieved.

The fostering of human resources of the Indonesian Navy is emphasized on the modernization of the human aspect in which human beings are placed in important positions within the organization of the Indonesian Navy. Thus, the development of human resources is a central point in building the strength and ability of the Indonesian Navy which is expected to determine the success of the Indonesian Navy to carry out the main task. Referring to this thinking, the fostering of human resources of the Indonesian Navy must be carried out conceptually, systematically, planned and continued. In this context coaching must be done under any circumstances, whether with full budget support or limited budget support, since humans are essentially living beings with specialties, namely feelings, thoughts and reason and dynamic knowledge, with that specificity between the scouted and the builder has the ability to be able to adapt to the environmental conditions being faced.

This paper has many literatures to support the research, such as literature with title Factors Affecting The Employee's Performance: A Case Study Of Banking Sector In Pakistan [11], Training and its Impact on the Performance of Employees at Jordanian Universities from the Perspective of Employees: The Case of Yarmouk University [12], [13], The Impact of the Motivation on the Employee's Performance in Beverage Industry of Pakistan [14], Impact of Organizational Culture on Employee Performance [15], Effect of Leadership Style on Employee Performance [16]

\section{Result And Discussion}

In order to respond to the increasingly complex task challenges, the Indonesian Navy must be able to carry out the reform and empowerment of its human resources to create superior and professional Indonesian Navy personnel. This is to remember that one of the keys to improve the professionalism of the Indonesian Navy is by improving the quality of human resources through improving the quality of education and training, perfecting work ethos, enhancing the relations of commanders and subordinates, and good leadership in every level of office. Improving the Quality of Navy Human Resources can be described at Figure 1 as follows: 


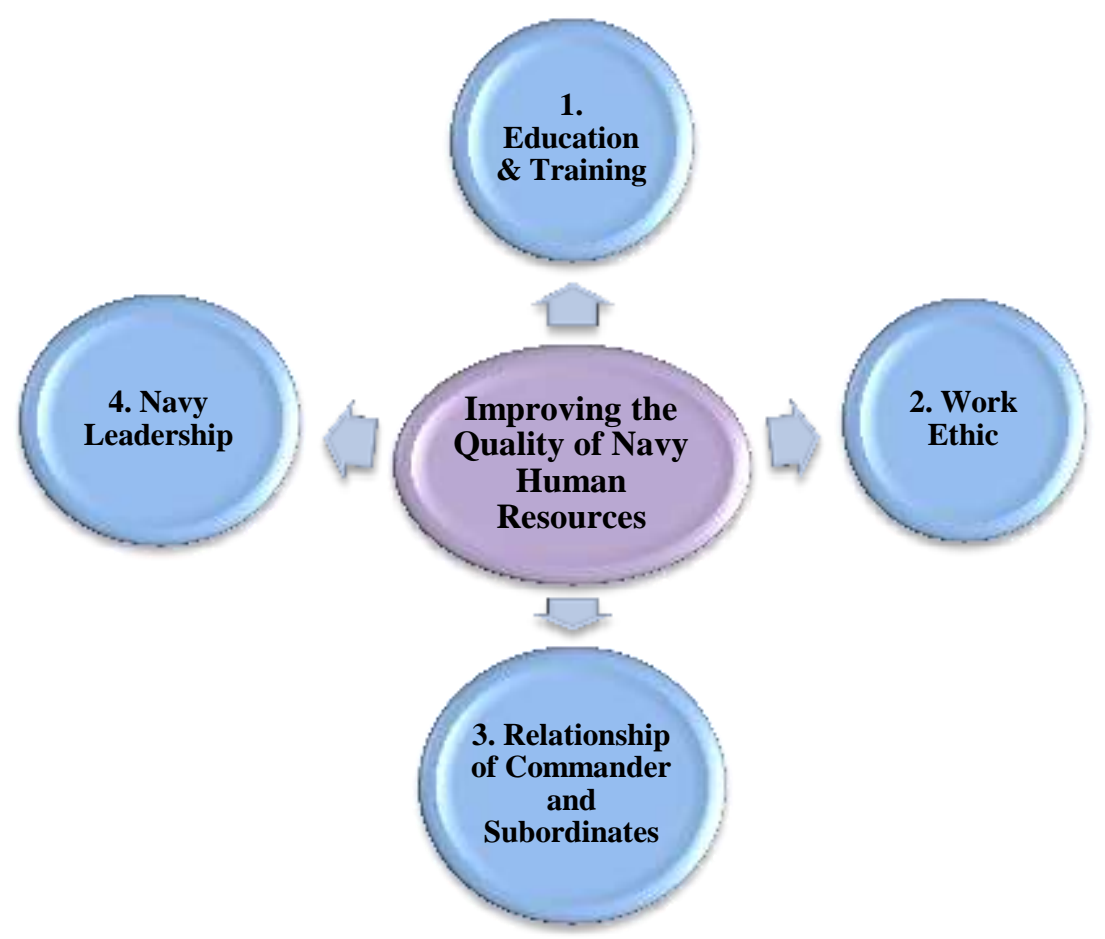

Figure 1. Improving the Quality of Navy Human Resources

Firstly, education and training aimed at equipping, maintaining and improving the quality of personnel are basically implemented within the Indonesian Navy, only in the context of present-day and strategic environmental influences of existing training and education enhanced by linking issues around the world of defense with the material and curriculum of the world of military education. Especially if it is associated with RMA where the factors of scientific and technological development are very influential to the defense sector, it is natural that education and training in the Indonesian Naval environment are developed and adapted to based on technological mastery, since the development of RMA has influenced the strategy and operational tactics.

Secondly, Completion of work ethic. Good work ethic will result in productive, efficient and capable personnel completing the job and job responsibilities proportionally and professionally. So far the environment of the Indonesian Navy still looks not yet effective and efficient way of working personnel so that productivity is not achieved optimally. To be able to improve work ethics required a fundamental change in the work environment of each unit at each level of office by making the standard work and personnel who do it by paying attention to: 1) Suitability, the right personnel in the right job so that productivity can be achieved, 2) Warranties, beliefs and beliefs that every work achievement will be rewarded, 3) Attention, that none of the work is not important even though the job is very easy to do, 4) Supervision, the most important part of the mechanism of a job as it relates to the timeliness of work completion and quality of work, 5) Evaluation, important factor to know how far the achievement of task, 6) Measures, sanctions in the event of delays or tasks are not resolved. By paying attention to these six factors then reward and punishment system can be enforced and better work ethos can be run.

Thirdly, increase the relationship of superior / commander and subordinate. That the success of the unit performs its main duty is not solely the duties and responsibilities of the Commander, but rather the joint responsibility. This is where the need for teamwork or cooperation between the commander and subordinates. In cooperation here it takes 1) Honesty on every personnel, 2) Responsibility of each personnel to perform the task properly and correctly, 3) Initiative of the leadership elements to make changes and 4) Mutual help between the commander and subordinate in realizing the goal or main task unit. Good cooperation can be realized through improving the relationship of commanders and subordinates, because if the commander's element is more intensive attention to his subordinates, then the reciprocity to be gained is the awareness and high responsibility of subordinates to carry out every job properly and correctly.

Fourthly, Navy Leadership. The most decisive factor in establishing a superior organization is good leadership. Similarly with the Indonesian Navy, as a military organization in order to become a strong organization, solid and professional in addition to having carried out the guidance of personnel, the last 
factor so that personnel can be fostered and directed towards a better change is a strong and reliable leadership factor in every rank of position in the Indonesian Navy. Forming strong and reliable leadership has often been discussed and discussed in the Indonesian Navy environment, as policy holders in the Indonesian Navy are well aware of the importance of leadership. But the implementation still feels lacking, this can be seen from the lack of portions of subjects on leadership in educational institutions in the Indonesian Navy. Although some say that a reliable leader was born by his era, but there are also leaders who are prepared. It is this prepared leader who needs to get the attention of the Indonesian Navy to try to realize it through educational institutions or leadership training. By putting more portion on early leadership formation, it is expected that good leaders in the Indonesian Navy will be able to build the Indonesian Navy into a reliable and respected organization and world-class.

\section{Factors Affecting Performance.}

According to the result of this research, the performance of an individual is determined by four factors, namely: Experience, Technical competence (hard skills), Behavioral competence (soft skills) and Attitude personality, as shown in the Figure 2. Factors Affecting of the Performance Navy Soldiers. Experience related to what has been done by someone, and can be measured through job history analysis, performance appraisal result, and track record owned. On the other hand, technical competence refers to what a person already knows, and can be measured through professional qualifications (eg from certificates and diplomas), or through a competency test or competency test. Behavioral and personality competencies, which are more related to the psychological aspects, relate to what a person can do. The description can be described at Figure 2 as follows:

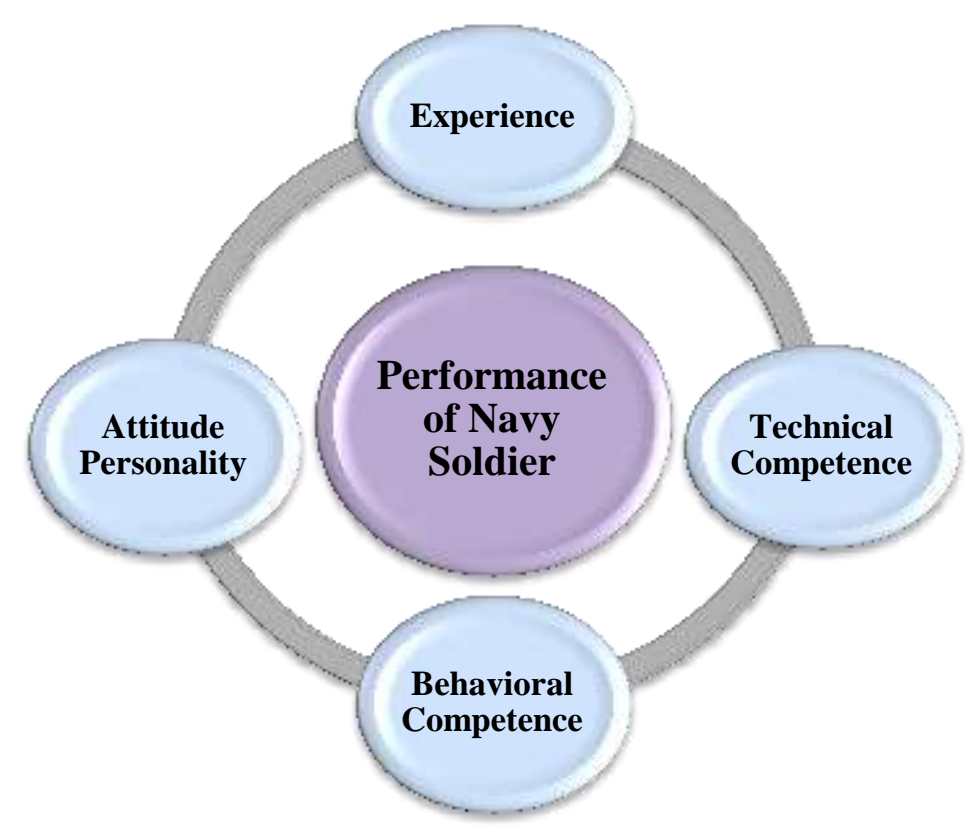

Figure 2. Factors Affecting of the Performance Navy Soldiers

A person who has sufficient experience and technical qualifications, may not necessarily have good performance, if the concerned is unable to show the behavior that supports the implementation of duties and positions. Behavioral competence can basically be measured through the so-called Assessment Center. Of these four factors (experience, technical competence, behavioral and personality competence), personality is regarded as the center of the optimal source of performance, and affects all other factors. In addition to these four factors, there is actually one more factor, namely institutional competence, which includes typical organizational values, so that it can influence one's performance. However, to this day, there is no scientific measuring tool that can be used to measure how far a person has made certain values as his lifeline.

\section{Competency Development.}

In terms of competence development, experience can essentially be enhanced by the provision of opportunities in various positions, while technical competence can be developed through education and 
training aimed at improving knowledge and skills. For behavioral competence, development programs that can be done are through various training programs and individual development that aims to change behavior, while organizational values that form the competence of institutions, can be instilled through indoctrination. Nevertheless, the human personality, whether derived from the innate (personality or IQ) traits, as well as those formed from the past, is something relatively settled and difficult to change.

\section{The Excellence-Based Approach.}

From an understanding of the personality, behavioral scientists have formulated the concept of strengths-based approach, which aims to place an individual according to his personality, and then develop his competence and experience. According to this thought, it is more useful to look for a personality that can be a person's strength, and then develop a competence that can be supported by that personality. For example, the innate nature of the extrovert is known to support interpersonal competence, so that the extroverted individual will be easier to develop in positions that require interaction with other humans.

On the basis of research, it is known that the competence associated with interpersonal flexibility is strongly influenced by the innate traits of controversy and adaptability, while the competencies associated with innovative thinking ability are influenced by the level of intelligence (IQ) possessed and the innate nature that is open to new experiences. Therefore, if an individual has a supportive personality, then the individual may be included in a behavioral development program related to interpersonal flexibility and innovative thinking, which in turn can result in a sociable and innovative individual.

\section{Conclusion}

The development of science and technology in the field of personnel management, civilian and military organizations in various countries, including Indonesia, has adopted competency-based personnel management methods in order to improve the performance of their organizations. The Ministry of Defense of the Republic of Indonesia, as part of the Government Bureaucracy Reform, has launched the concept of competence-based personnel development in the ranks of the Indonesian National Army. Thus, the Indonesian Armed Forces must certainly make various improvements in the field of personnel development in order to apply competent skills-based personnel management methods appropriately. Through the implementation of appropriate competency-based personnel management methods, it is expected that the future performance of the Indonesian National Armed Forces personnel will be optimized.

In the context of behavioral competence, the main objective in developing behavior that supports optimal performance is the mapping of relationships between personalities that can support the behavioral competencies expected within the organization. Given the personality is difficult to change, then after the measurement of personality through psychological examination in a classical and obtained psychological data of a person, then can be measured behavioral competence. For individuals who have inadequate behavioral competence, can be included in the development program so that in the future concerned will be able to show optimum performance.

\section{Acknowledgement}

The authors greatly acknowledge the support from Sekolah Tinggi Ilmu Ekonomi Indonesia STIESIA Surabaya and Indonesian Navy Institution for providing necessary resources to carry out this research work. The authors are also grateful to the anonymous reviewers and journal editorial board for their many insightful comments, which have significantly improved this article.

\section{References}

[1] Singh, J. Kumar, Jain dan D. Mini, "A Study of Employees Job Satisfaction and its Impact on their Performance,” Journal of Indian Research, pp. 105-111, 2013.

[2] Latif dan M. Shahzad, "Impact of Employees Job Satisfaction on organizational Performance," European Journal of Business and Management, pp. 166-171, 2013.

[3] Sageer, Alam, Rafat, D. Sameena, Agarwal dan M. Puja, "Identification of Variables Affecting Employees Satisfaction,” IOSR Journal of Business and Management (IOSR-JBM), pp. 32-39, 2012. 
[4] Parvin dan M. Mahamuda, "Factors Affecting Employee Job Satisfaction of Pharceutical Sector," Australian Journal of Business and Management Research, pp. 113-123, 2011.

[5] Khan, A. Hussain, Aleem dan Muhammad, "Impact of satisfaction on employee turnover : An emirical study of Autonomous Medical Institution of Pakistan,” Jornal of International Studies, pp. 122-132, 2014.

[6] Rania, Sakthivel, Kamalanabhan dan Selvarina, "Work/Life balance Reflection on Employees Satisfaction," Serbian Journal of Mangement, pp. 85-96, 2011.

[7] Mashood dan Ayesha, "Factors Affecting Employee Satisfaction of Public and private sector organization of Pakistan,” International Journal of Human Resources Studies, pp. 97-121, 2014.

[8] Chukwuma, Maduka, Edwin, Okafor dan D. Obiefuna, "Effect of motivation on employee Productivity : A study of Manufacturing Comanies in Nnewi," International Journal of Managerial Studies and Research, pp. 137-147, 2014.

[9] Elqadri, Z. Mustafa, Wardoyo, D. T. Wijayanti dan Priyono, "The Influence of motivation and discipline work againts Employee work productivity Tonaan Market," Review of European Studies, pp. 59-66, 2015.

[10] Iqbal, M. Ijaz, F. Latif dan H. Mushtaq, "Factors Affecting The Employee's Performance: A Case Study Of Banking Sector In Pakistan.," European Journal of Business and Social Sciences, pp. 309-318, 2015.

[11] M. M. M. Al-Mzary, A. (. H. D. Al-rifai dan M. O. E. AlMomany, "Training and its Impact on the Performance of Employees at Jordanian Universities from the Perspective of Employees: The Case of Yarmouk University," Journal of Education and Practice, pp. 128-140, 2015.

[12] R. I. Vosloban, "The Influence of the Employee's Performance on the company's growth - a managerial perspective," Procedia Economics and Finance journal, pp. 660-665, 2012.

[13] H. Zameer, S. Ali, W. Nisar dan M. Amir, "The Impact of the Motivation on the Employee's Performance in Beverage Industry of Pakistan," International Journal of Academic Research in Accounting, Finance and Management Sciences, pp. 293-298, 2014.

[14] M. Awadh dan M. S. Alyahya, "Impact of Organizational Culture on Employee Performance," International Review and Business Research, pp. 168-174, 2013.

[15] N, A. S dan H. N, "Effect of Leadership Style on Employee Performance," Arabian Journalof Business and Management Review, pp. 2-6, 2015. 